Revista Eletrônica Geografar, Curitiba, v. 2, Resumos do VI Seminário Interno de Pós-Graduação em Geografia, p. 32-32. Junho/2007

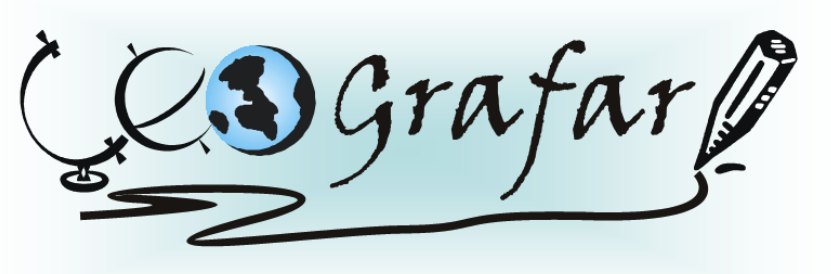

Revista Eletrônica do Programa de Pós-Graduação em Geografia - UFPR

\title{
RISCOS AMBIENTAIS RELACIONADOS AO ADENSAMENTO INDUSTRIAL APÓS A CONSOLIDAÇÃO DO PÓLO AUTOMOTIVO NO AGLOMERADO METROPOLITANO DE CURITIBA1
}

\author{
HELENA DOS SANTOS LISBOA ${ }^{1}$
}

A presente pesquisa pretende estabelecer uma avaliação dos riscos ambientais decorrentes da recente industrialização em áreas de mananciais no aglomerado metropolitano de Curitiba. Esta recente industrialização relaciona-se a reestruturação produtiva paranaense, principalmente a partir da década de 1990, que priorizou a atração de investimentos internacionais. Neste aspecto as políticas para atração desses investimentos, voltaram-se para as indústrias ligadas ao setor automotivo, visando, sobretudo o aglomerado metropolitano de Curitiba, inaugurando um Pólo Automotivo, principalmente centrado nas montadoras Renault e Audi-Volkswagen. As montadoras automobilísticas têm um papel significativo na configuração da estrutura produtiva, atuando como coordenadoras do arranjo espacial, atraindo grande número de empresas fornecedoras de peças e serviços. Frente a esta nova realidade, muitas áreas impróprias à instalação industrial foram ocupadas, neste sentido, salienta-se principalmente as áreas de mananciais. Desta forma, a pesquisa pretende fazer uma análise dos possíveis riscos ambientais por meio da elaboração de um questionário, junto as indústrias automotivas que encontram-se dentro ou próximas de áreas de mananciais. Pretende-se avaliar, o sistema produtivo, fatores que influenciaram na localização industrial, quantidade e características dos resíduos gerados, a forma de destinação dos mesmos, políticas ambientais (reciclagem, reuso, certificação ISO) entre outros. A metodologia se baseará também na verificação do crescimento industrial após a consolidação do Pólo Automotivo, na avaliação do crescimento populacional por setor censitário, e em dados coletos junto a IAP (Instituto Ambiental do Paraná), Sanepar (Companhia de Saneamento do Paraná) e Suderhsa (Superintendência de Desenvolvimento de Recursos Hídricos e Saneamento Ambiental). Como resultado parcial, sete indústrias já responderam o questionário, dentre estas destaca-se as montadoras Renault, Audi-Volkswagen e Volvo. Verifica-se que os incentivos governamentais foram centrais para localização da maioria das indústrias. Todas possuem uma considerável geração de resíduos, porém apenas uma não possui políticas voltadas ao ambiente, como certificação ISO 14001 e práticas de reuso e reciclagem.

Palavras-Chave: Aglomerado Metropolitano; riscos ambientais; setor automotivo.

${ }^{1}$ Mestranda em Geografia - UFPR - email: helena_lisboa@yahoo.com.br Orientadora: OLGA LUCIA C. F. FIRKOWSKI 